Research paper

\title{
The Middle Devonian plant assemblage from Dechra Aït Abdallah (Central Morocco) revisited
}

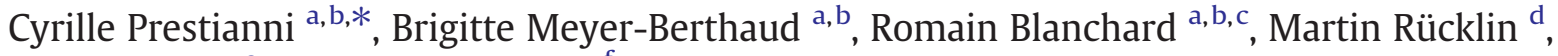 \\ Gaël Clément ${ }^{\mathrm{e}}$, Philippe Gerrienne ${ }^{\mathrm{f}}$ \\ a Université Montpellier 2, UMR AMAP, Montpellier, F-34000 France \\ b CNRS, UMR AMAP, Cirad, TA-A51/PS2, Boulevard de la Lironde, F-34398 Montpellier cedex 5, France \\ c 286 rue d'Orléans, 76230 Bois-Guillaume, France \\ d School of Earth Sciences, University of Bristol, Wills Memorial Building, Queen's Road, Bristol BS8 1RJ, UK

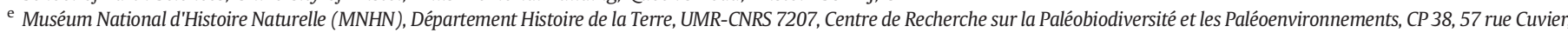 \\ F-75231 Paris cedex 5, France \\ ${ }^{\mathrm{f}}$ Paléobiogéologie, Paléobotanique, Paléopalynologie, Département de Géologie, Université de Liège, B18, Sart Tilman, B-4000 Liège, Belgium
}

\section{A R T I C L E I N F O}

Article history:

Received 29 November 2011

Received in revised form 27 March 2012

Accepted 28 March 2012

Available online 5 April 2012

\section{Keywords:}

Middle Devonian

Gondwana

Morocco

fossil plants

Dechra Aït Abdallah

\begin{abstract}
A B S T R A C T
The composition of the allochthonous flora from Dechra Ait Abdallah (Central Morocco), initially described by Termier and Termier (1950), is reassessed from newly collected fossil material. Our work provides an updated taxonomic treatment of the plant remains. The flora comprises two lycophytes (including Leclercqia complexa), the probable iridopterid Anapaulia moodyi, and two aneurophytalean progymnosperms: Rellimia sp. and "Aneurophyton" maroccanum. Our revision confirms the Termiers' main conclusions that this Devonian flora is to date the most diverse and best known from Africa. Based on the complete paleontological evidence available from this locality, a Givetian age is as likely as an Eifelian age for the flora. The abundance of plant remains associated with the extreme scarcity of fertile organs may be accounted for by a taphonomic sorting, climatic conditions and/or specific ecological strategies. The flora of Dechra Ait Abdallah shows similarities with the Middle Devonian floras from the European part of Laurussia. This suggests that the paleogeographical position of Central Morocco permitted exchanges with Laurussia, and infers proximity of the latter with the north-western border of Gondwana during Middle Devonian times.
\end{abstract}

(C) 2012 Elsevier B.V. All rights reserved.

\section{Introduction}

The Early to Middle Devonian are times of high origination rate and increasing diversity for land plants (Raymond et al., 1985; Raymond and Metz, 1995; Cascales-Miñana et al., 2010; Gutak et al., 2010). This pattern has been linked to the acquisition of new traits enabling the evolution of complex body plans that were more tightly adapted to their local habitats than earlier land plants (Chaloner and Sheerin, 1979; Hotton et al., 2001; Greb et al., 2006). The connection between the taxic diversification of Devonian plants and paleogeography is less clear. One of the limitations in recovering phytogeographical patterns for the Devonian is the low number of reliable assemblages available for the paleocontinent Gondwana (Raymond, 1987; Raymond and Metz, 1995; Edwards et al., 2000). Most paleobotanical data come from the paleoequatorial belt, notably from the Laurussia continent and the China block which have been, for historical reasons, intensively studied

\footnotetext{
* Corresponding author at: Institut Royal des Sciences Naturelles de Belgique, Rue Vautier 29, Bruxelles, B-1000, Belgium.

E-mail addresses: Cyrille.prestianni@naturalsciences.be (C. Prestianni), meyerberthaud@cirad.fr (B. Meyer-Berthaud).
}

(see Taylor et al., 2009 for summary). The Devonian plant record of Gondwana and especially of its northern rim is scarce, poorly dated and its taxonomic treatment is sometimes inaccurate (Lemoigne, 1967; Lejal-Nicol, 1975; Lejal-Nicol and Massa, 1980; Streel et al., 1990a, 1990b). Based on such data, a marked provincialism has been assumed for the terrestrial vegetation of the Early Devonian (Raymond et al., 1985; Raymond, 1987; Edwards and Berry, 1991), followed by cosmopolitan floras in the Givetian and early Late Devonian (Streel et al., 1990a, 1990b, 2000).

The proximity of North Africa and Laurussia during the Devonian suggested by a number of paleogeographic reconstructions (e.g., Streel et al., 1990a, 1990b; Scotese and McKerrow, 1990; Matte, 2001; Blakey at http://jan.ucc.nau.edu/ rcb7/370_Devonian_2globes.jpg), and the possible location of Morocco at the interface of two climatic belts (Scotese, 1999) make this geographical area of particular interest. North Africa, and especially Morocco, may have represented a main site for floral exchanges between Gondwana and Laurussia, and between a warm temperate climatic belt to the south and a dry subtropical belt to the north.

In 1950, Henri and Geneviève Termier described a diverse and well-preserved plant assemblage from marine deposits at Dechra Aït 
Abdallah in Central Morocco. They first attributed an Eifelian age (Termier and Termier, 1950), but later revised this opinion and proposed a Givetian age (Termier et al., 1975, 1977). They reported seven genera, a number of them such as Aneurophyton, Cordaianthus and "Archaeopteris" suspected to have been misidentified (Fairon-Demaret and Régnault, 1986; Gerrienne et al., 2010). The Termiers' plant collection was not deposited in any Museum nor University collection and we have been unable to find it so far. Some of us (BMB, GC, MR, PG) visited the Termier and Termier locality in 2000 and 2007 and collected new fossil plants. Our goals, in this paper, are to provide updated information on the paleoflora of this particularly favorable site based on this new collection, to document its composition more accurately, to discuss its age, to assess the intensity of floral exchanges between Gondwana and Laurussia, and to discuss the paleogeographical and paleoclimatic significance of this Moroccan assemblage.

\section{Previous studies of the flora}

The occurrence of fossil plants from the marine deposits of Dechra Aït Abdallah was first accounted in a short report by Termier and Termier (1947), then more extensively analyzed in a later publication by the same authors (Termier and Termier, 1950). They attributed the flora an Eifelian age and described it as the most important record of Devonian plants in Africa. The flora consisting of adpressions included the following taxa: Asteroxylon elberfeldense Kräusel \& Weyland, Psilophyton princeps Dawson, Hyenia cf. elegans Kräusel \& Weyland, Aneurophyton maroccanum nov. sp., Scougouphyton abdallahense nov. gen. nov. sp., Cordaianthus devonicus Dawson, "Archaeopteris"? rotundifolia nov. sp., and incertae sedis remains. Termier and Termier (1950) provided short descriptions and hand drawings for each taxon but no photograph. They emphasized the resemblance of the Moroccan flora with German plant assemblages of Middle Devonian age, especially that from Elberfeld. In later accounts on the geology of the Dechra Aït Abdallah area, Termier et al. $(1975,1977)$ revised the age of the plant-bearing beds and assigned them to a Givetian age.

Following the two field trips in Morocco made by some of us to locate the plant beds and initiate a new collection of fossil plants, Gerrienne et al. (2010) reported the discovery of a fertile axis identified as Rellimia sp. This report was of some importance, not only because fertile remains are rare in the plant assemblage of Dechra Aït Abdallah, but also because it is the first record of the aneurophytalean genus Rellimia in Africa. On the basis of associated tentaculites, the authors suggested a late Emsian age for the plant-bearing beds which would make this Moroccan specimen the earliest representative of the genus.

\section{Geological setting and stratigraphy}

The Dechra Aït Abdallah area is located about $30 \mathrm{~km}$ north of Khenifra and $10 \mathrm{~km}$ northwest of Mrirt (Fig. 1B, C). Its geological interest has been discussed by Termier and Termier in a number of publications (e.g. Termier and Termier, 1947, 1950, 1970, 1971, 1972; Termier et al., 1975, 1977). More recently, unpublished manuscripts, one PhD dissertation (Faik, 1988) and two master theses (Bohn, 1993; Grobe, 1993) provided updated information on the geology of Dechra Ait Abdallah (alternative spelling: Dchar Ait Abdallah). This region is located in the north-eastern part of the Moroccan Meseta called "Massif Central" (Fig. 1A). It is characterized by extensive Carboniferous deposits and a more limited cover of Devonian sediments (Michard, 1976). The plant locality occurs south of a low pass called either "Col Dar Caïd" (Termier and Termier, 1947) or "Aguerd n'Asdeit" (in all subsequent publications), on the southeastern flank of a hill referred to as Lachaq in Faik (1988) and Bohn (1993) (Fig. 1C). Plants occur in several centimetric to decimetric gray silty limestone beds. These outcrops belong to one of the several allochthonous tectonic blocks consisting of Middle to Late Devonian sediments, and embedded within Upper Viséan sedimentary rocks (Fig. 1B; Bouabdelli et al., 1989; Grobe, 1993, 1997). The Devonian sediments may have been deposited eastward, in a region that was uplifted and subsequently displaced during Late Viséan times (Grobe, 1997). The original depositional environment has been interpreted as shallow marine with regular fluvial pulses.

The uncertainties about the age of the plant deposits are largely due to the structural complexity of the region. Originally interpreted as "Couvinian" (Eifelian) from the tentaculites and phacopid trilobites associated with the plant remains (Termier and Termier, 1947, 1950,
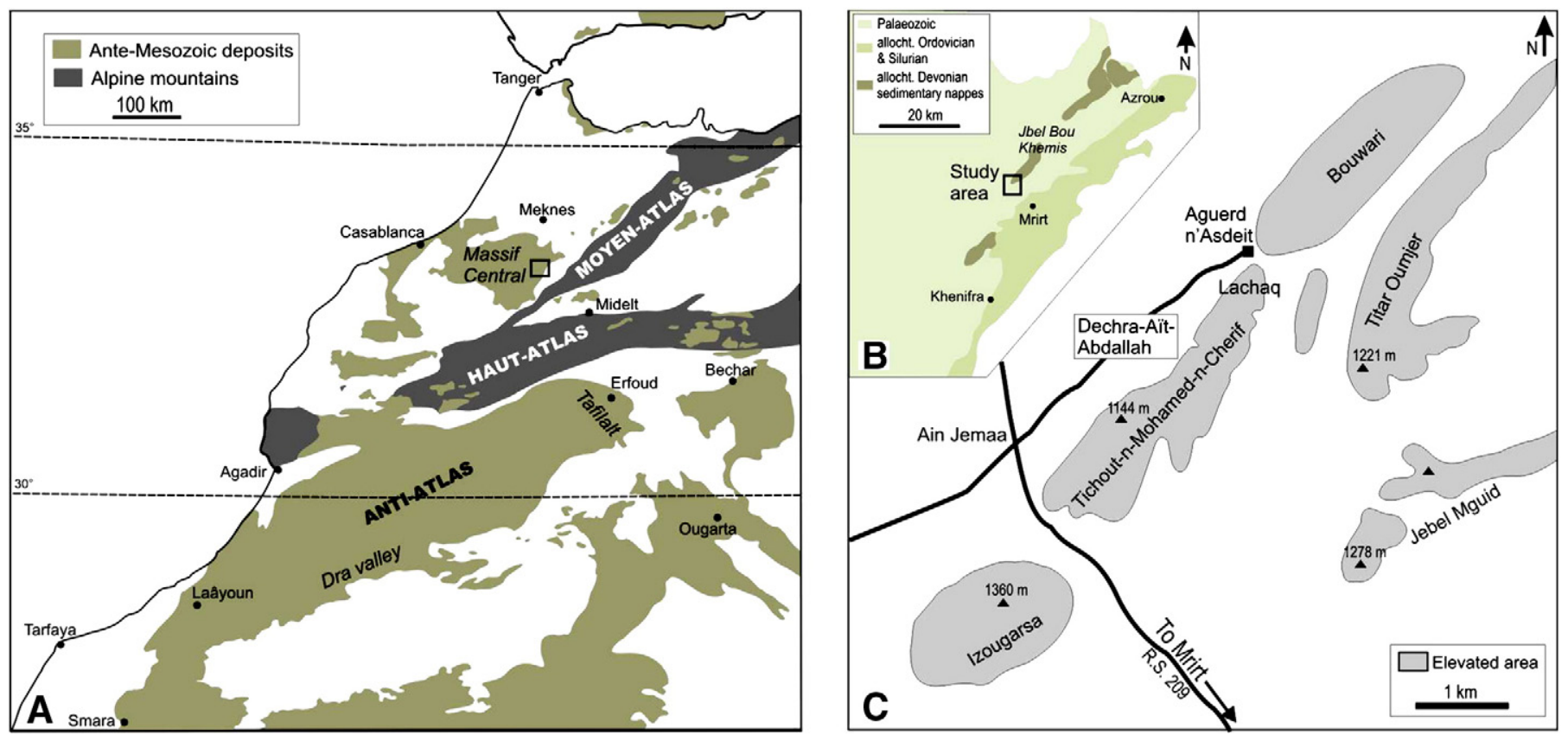

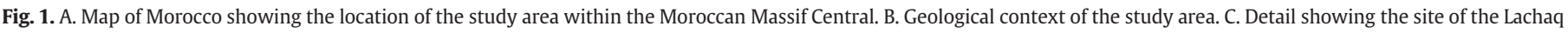
hill where the new material of plants was collected.

Panel A is from Michard (1976). Panel B is from Grobe (1997). Panel C is from Bohn (1993). 


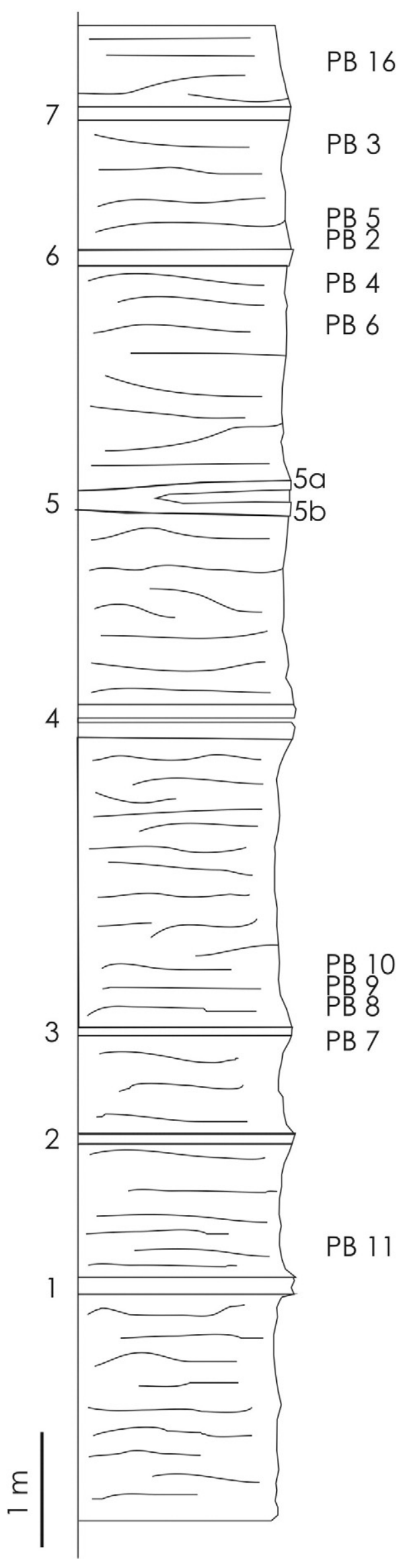

1970), the limestone yielding plants was then included by Termier et al. (1975) in the "Menhar-Zizouit Formation" that ranges from Givetian to lower Frasnian. The Givetian age of the plant beds was assumed from their occurrence between purple lutites corresponding to a fluvio-marine episode with Givetian pterinopectinid bivalve Ateyapecten scougouicus (Termier and Termier, 1973), and reef limestones with Givetian-Frasnian stromatoporoids, tabulates and associated invertebrate faunas (Termier et al., 1975). Faik (1988), who detailed the stratigraphy and structural evolution of the Paleozoic deposits in the vicinity of Mrirt, assigned the Lachaq outcrops to the "Tichout-n-Mohamed-n-Cherif Member" of the "Dchar Aï Abdallah Formation". His Lachaq section displayed two superimposed nappes, the outcrops ranging from Frasnian to Famennian based on conodonts that are locally abundant according to Faik (1988). Bohn (1993) and Grobe $(1993,1997)$ also assessed the structural complexity of the Dechra Aï Abdallah area and the occurrence of allochthonous nappes consisting of Devonian sediments. Bohn (1993) reexamined the Lachaq section and mostly based his conclusions on Faik's work and on one single new conodont-rich sample. Neither Faik nor Bohn mentioned the occurrence of plant fossils at Lachaq. Lack of illustration, as well as the large scale used by these authors to draw the logs, makes their results difficult to interpret in the context of the present work.

During the course of our field investigation, tentaculites and trilobites intermixed with the plant remains were collected because of their biostratigraphic potential. Tentaculites were studied by Hubert Lardeux (Université Rennes 1) who qualified the samples as rich but not optimally preserved. He recognized the genera Styliolina Karpinsky (Styliolinida) and Viriatellina Bouček (Nowakiida) and identified some specimens from the base of the hill as Viriatellina aff. pseudogeinitziana armoricana Lardeux; in its type locality, this Viriatellina subspecies is Zlichovian (late Emsian) in age (Lardeux, pers. com.; Gerrienne et al., 2010). Trilobites are also poorly preserved, deformed and lacking their exoskeleton. They were checked by Raimund Feist (Institut des Sciences de l'Evolution, Montpellier, France) who assigned all the identifiable fragments to a single phacopid species, probably Struveaspis maroccanica; this species was originally described in lower Eifelian (sulcata tentaculite zone) beds of the Moroccan Massif Central (Alberti, 1970) (Feist, pers. com.). Our different attempts to recover palynomorphs and conodonts from samples collected from the plant-bearing beds were unsuccessful.

\section{Materials and methods}

Two field sessions, in 2000 and 2007, allowed the collection of some 150 plant fragments from the southeastern flank of the Lachaq hill at Dechra Aït Abdallah (Figs. 1A-C and 2). All the fossils are incomplete, representing fragments of individual axes or of branched systems lacking both proximal and distal ends. They are preserved as coalified compressions or impressions. The specimens were prepared using triangular needles following the dégagement technique (Fairon-Demaret et al., 1999). Macrophotography of specimens was undertaken with a Nikon D-70 camera and a macro lens. Details were photographed using an Olympus D72 camera adapted on an Olympus SZX9 binocular loupe. All pictures were taken using dry crossed polarizing filters to enhance contrast. Palynological preparations showed the matrix to be barren in palynomorphs (Gerrienne et al., 2010). The fossils are housed in the Palaeobotany Collections of Université Montpellier 2, France.

Fig. 2. Stratigraphic log of the Lachaq section showing position of the plant layers. The sedimentation is dominated by gray silty limestone beds. All plant layers are positioned. 


\section{Plant descriptions}

\subsection{Lycophytes - Zosterophyllopsida}

\subsubsection{Spiny zosterophyll}

5.1.1.1. Material. Two specimens of this plant have been found, 16DAA-108 (Plate I, 1 and 2) and 12-DAA-99 (Plate I, 3 and 4). They were respectively collected in plant bed 16 and in plant bed 12 (Fig. 2).

5.1.1.2. Description. The longest specimen, 12-DAA-99, is $52 \mathrm{~mm}$ long with a main axis diameter of $1.8 \mathrm{~mm}$ proximally (Plate I, 4). It is preserved as an impression, with a small amount of organic material remaining. The plant surface is brown to orange in color. The second specimen is a compression fossil and has a basal stem diameter of $1.6 \mathrm{~mm}$ (Plate I, 1). Axes branch through slightly unequal dichotomies. Up to four dichotomies are observed (Plate I, 1). Stems are covered with stout deltoid spines ranging between 1.2 and $1.6 \mathrm{~mm}$ long and between 0.9 and $1 \mathrm{~mm}$ wide at base (Plate I, 1-4). Spines project from the stems at wide angles. They are relatively densely arranged. They are unevenly distributed but may appear spirally organized at places (Plate I, 3). There are no additional organs resembling subordinate branches preserved at, or close to, the levels of dichotomies. No fertile parts have been found.

5.1.1.3. Interpretation. This plant corresponds to specimens assigned to Psilophyton princeps in Termier and Termier (1950, planche-texte 1, Fig. 1-3). Several Devonian plants share a set of characters comparable to these specimens. They are Anisophyton (Remy et al., 1986), the monospecific genus Konioria (Zdebska, 1982) and Sawdonia (Hueber, 1971; Gensel et al., 1975). Two species of Anisophyton are known, Anisophyton gothanii and Anisophyton potoniei. In both, the stems preserved in compression are characterized by thickened margins and by spines presenting flat tips. None of these characters have been observed in our specimens. Similarly, axes of Konioria andrychoviensis are characterized by a thickened margin and thus also differ from the Moroccan specimens. The branching pattern and size of the two specimens together with the shape, size and arrangement of the spines characterize members of the zosterophyll or allied genera Sawdonia, Ensivalia, Odonax or Faironella (Hueber, 1971; Gerrienne, 1996a, 1996b). The lack of reproductive structures, however, prevents from any firm taxonomic identification of the Moroccan specimens. Comparable spiny zosterophylls range from the Lochkovian to the lower Frasnian (Edwards et al., 2000). They have a wide paleogeographical distribution in Laurussia [USA, Canada and Europe (Gensel and Andrews, 1984), Kazakhstan and Siberia (Saian-Altai) (Jurina, 1988)]. To date, the single report of a Sawdonia-like plant in Gondwana comes from Givetian beds of the Lower Member of the Campo Chico Formation in Venezuela (Berry et al., 2000).

\subsection{Lycophytes - Lycopsida}

\subsubsection{Leclercqia complexa}

5.2.1.1. Material. Three specimens have been collected, in plant beds 11,3 and 1 (Fig. 2). They are respectively numbered 11-DAA-93, 3DAA-44 (Plate I, 5-7) and 1-DAA-12.

5.2.1.2. Description. The preserved fragments of stems measure up to $8 \mathrm{~cm}$ long and 1.5 to $2 \mathrm{~mm}$ wide (Plate I, 5). They show no conspicuous tapering and are all unbranched. They are preserved as compressions, with a small amount of organic material remaining. The stem surface is dark brown to black in color. Attached leaves are most evident on the stem margins. On the stem surface, leaf bases alternate in successive gyres. At the widest part of the stems, there is a maximum of four leaf bases visible at one level which suggests a maximum of six to eight leaves per gyre (Plate I, 5). Several leaves have been uncovered (Plate I, 6 and 7; Fig. 3). They are threedimensional. Their proximal portion, attached to the stem, is 1.5 to $2.5 \mathrm{~mm}$ long and about $0.4 \mathrm{~mm}$ wide. It divides distally into five segments of unequal length and arranged in different planes. The central segment is long and curved downwards (Plate I, 7; Fig. 3b). The other four segments are short, arranged in two pairs at either sides of the medial segment and are situated in the same plane as the proximal portion of the leaf (Plate I, 6; Fig. 3a). All segments have a well-defined acute tip.

5.2.1.3. Interpretation. Termier and Termier (1950, Planche-texte 2 , Fig. 18) illustrated a similar plant. They were unable to assign it to any specific taxon and simply referred this specimen to "terminaisons couvertes de feuilles" ("extremities of axes covered with leaves"). The genus Leclercqia Banks et al. (1972) emend. Bonamo et al. (1988) and Gensel and Kasper (2005) (Protolepidodendrales) is the only herbaceous lycopsid of Devonian age comprising plants with leaves divided into five segments. Three species are presently distinguished in this genus mainly on the basis of leaf morphology (Bonamo et al., 1988; Gensel and Kasper, 2005; Xu et al., 2011). Leaves of Leclercqia uncinata from the late Middle Devonian of Xinjiang are divided into seven segments, the central one being distinctly long and hooked. Leclercqia complexa and Leclercqia andrewsii are the only species with leaves commonly presenting five segments. The leaves of $L$. complexa are characterized by a three-dimensional organization in which the central segment is perpendicular to the other four (Banks et al., 1972). By contrast $L$. andrewsii presents bidimensional leaves in which all segments are situated in the same plane (Gensel and Kasper, 2005). Although fragmentary, the specimens studied here are attributed to L. complexa because of the three-dimensional organization of the leaves. The stratigraphic record of this species ranges from the late Emsian to the late Givetian. Remains of $L$. complexa are reported from the paleoregions Laurussia (USA, Canada, Europe) (Gensel and Albright, 2006), Kazakhstan (including Xinjiang; Xu and Wang, 2008; Xu et al., 2011), Gondwana (Berry, 1994; Meyer-Berthaud et al., 2003) and probably Siberia (Berry, 1996).

\subsubsection{Undetermined lycopsid}

5.2.2.1. Material. Five specimens have been collected, one from the lowermost plant bed (DAA-07-35), two from plant bed 11 [DAA-07-1 (Plate I, 8-11) and DAA-07-4] and two from plant bed 10 [10-DAA-71 and 10-DAA-82].

5.2.2.2. Description. The specimens contain 1.1 to $1.5 \mathrm{~cm}$ wide and 1.8 to $10 \mathrm{~cm}$ long unbranched portions of axis with no leaves attached. Two specimens that correspond to the molds, or "negatives", of the axis surface (Plate I, 8) show a dense pattern of small rhomboidal surfaces arranged in spiral interpreted here as leaf bases. A maximum of eight leaf bases are visible per gyre which implies a maximum of sixteen for each complete rotation. Leaf bases are about two times wider than high, ranging from 2.2 to $2.4 \mathrm{~mm}$ in width and 1.1 to $1.3 \mathrm{~mm}$ in height. In the best preserved specimen, the leaf bases are separated by a narrow rim (150-220 $\mu \mathrm{m})$ presenting a conspicuous thickening at one angle (Plate I, 9 at arrows). They also exhibit a circular (Plate I, 10 at arrow), more rarely transversely elongated, elevation in the central or upper half of the leaf base. A reconstruction of the positive surface of the axis using a latex cast (Plate I, 11) shows that individual leaf bases are contiguous, characterized by a notch possibly positioned adaxially (Fig. 4), and are therefore not strictly diamond-shaped. The circular or transverse elevated structure noted on the fossils (Plate I, 10 at arrow) is relatively inconspicuous on the latex cast and may either represent a vascular trace or the narrow insertion of the proximal part of a leaf. 


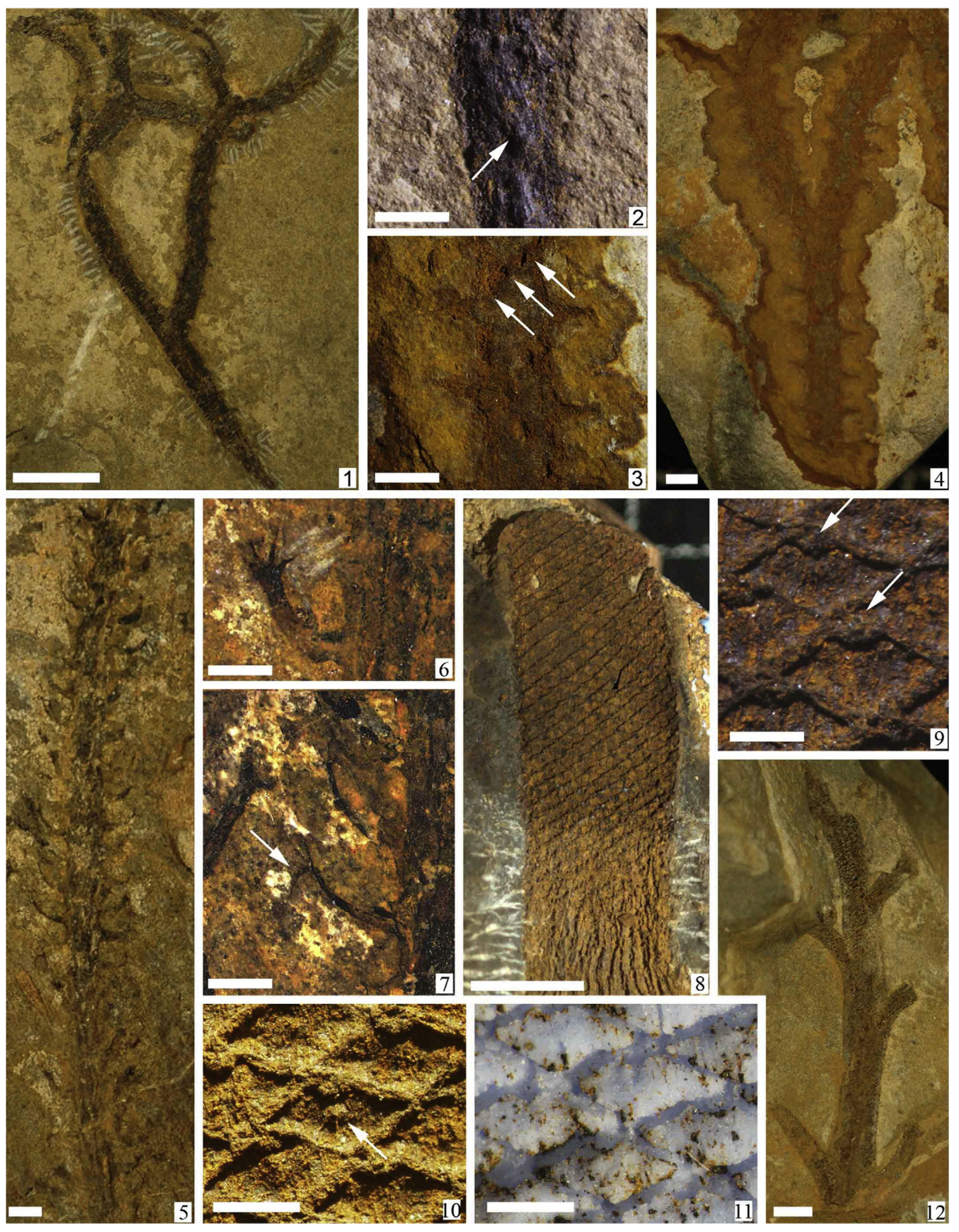




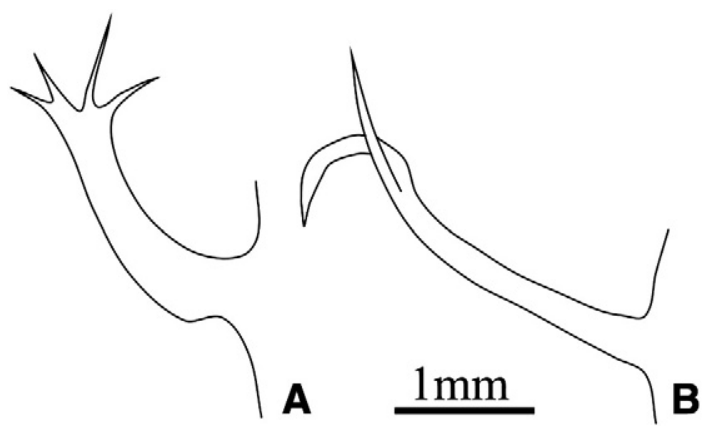

Fig. 3. Camera lucida drawing of two Leclercqia complexa leaves (same specimen as Fig. 5).

5.2.2.3. Interpretation. This type of plant was not mentioned in Termier and Termier original publications. The surface pattern of the axis as it appears on Plate I, 8 superficially resembles that of Leptophloeum, an arborescent lycopsid genus characterized by spirally arranged, contiguous, and well defined rhombic leaf bases. Leptophloeum was established by Dawson (1861) for plant fossils preserved as compressions from the Upper Devonian (Famennian) of Maine (U.S.A.). It has then been reported for Late Devonian deposits of Europe, Asia, Africa and Australia (Lemoigne, 1982). Most descriptions of the probably synonymous (Sze, 1952) species Leptophloeum rhombicum Dawson and Leptophloeum australe (McCoy) Walton are based on larger axes than the Moroccan specimens. Leptophloeum leaf bases are large, each with a very small vertical oval leaf scar situated in the center or in the upper half of the leaf base (Sze, 1952; Lemoigne, 1982; Li et al., 1986). The presence of a ligule was reported by Lemoigne (1982) but this has still to be confirmed (Li et al., 1986). In order to better assess the size variation of the Leptophloeum leaf bases, we visited the Australian collection of L. australe at the Natural History Museum of London. Specimens measuring $8 \mathrm{~mm}-16 \mathrm{~mm}$ in width and comparable in size to the Moroccan axes have larger leaf bases which range from $2,7 \mathrm{~mm}$ to $3,5 \mathrm{~mm}$ wide. Three to four leaf bases only are observed on each flattened faces (between six and eight per gyre). In all these specimens, the oval leaf scar is well marked, unlike the inconspicuous circular or transversely elongated structure on the leaf bases of the Moroccan specimens.

The small size and high density of the leaf bases, their outline, and the lack of a well-marked leaf scar characterizing the specimens from Dechra Ait Abdallah are suggestive of the surface patterns of drepanophycalean and protolepidodendralean-like axes with persistent leaves. The Moroccan specimens, by their rhomboidal leaf bases that are closely arranged and often wider than high, recall the Early to Middle Devonian species Drepanophycus gaspianus which is common in North America and Europe (Stockmans, 1940, Grierson and Banks, 1963; Grierson and Hueber, 1968; Gerrienne, 1993). Halleophyton zhichangense, from the Posongchong Formation in southern China ( $\mathrm{Li}$ and Edwards, 1997), is another plant resembling D. gaspianus and the axes from Dechra Ait Abdallah. In D. gaspianus and H. zhichangense

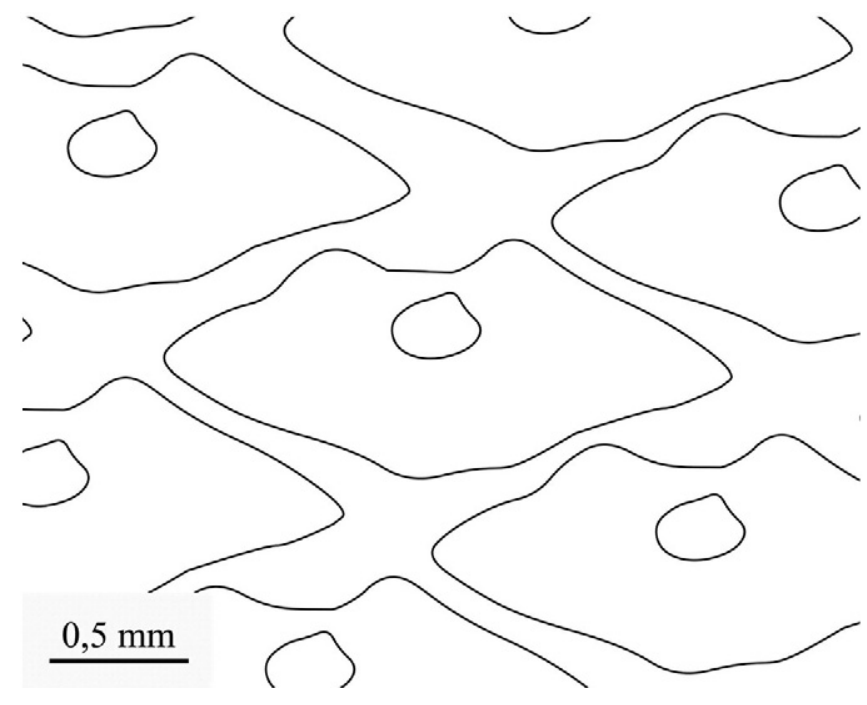

Fig. 4. Schematic reconstruction of the undetermined Lycopsida (same specimen as Fig. 9).

however, leaf bases occur in flattened helices and leaf insertion is wide, marked by a pronounced transverse or convex ridge. In Gondwana, two specimens reported from the Lower to Middle Devonian deposits of the San Juan Province in Argentina compare well to the Dechra Ait Abdallah specimens by the size and general outline of the leaf bases. One is a $9 \mathrm{~mm}$ wide stem fragment identified by Frenguelli (1954) as Cyclostigma confertum and later compared to the so-called species Archaeosigillaria picosensis (Kräusel and Dolianiti, 1957). Its leaf bases, however, tend to be more hexagonal than those of the Moroccan specimen. The second specimen from Argentina, which is also $9 \mathrm{~mm}$ wide, was referred to as specimen LPPB 13267 by Edwards et al. (2009) and illustrated in their Fig. 7c. The leaf bases of this specimen do not show any obvious notch, a feature possibly specific to the Moroccan stems. Because leaf laminae were not preserved, Edwards et al. (2009) did not assign their fossil to any taxon but simply inferred that it belonged to an herbaceous lycophyte with persistent leaf bases. The same approach is taken in this paper for the undetermined lycopsid from Dechra Aït Abdallah.

\subsection{Cladoxylopsida - Iridopteridales}

\subsubsection{Anapaulia moodyi}

5.3.1.1. Material. This plant is represented by a single specimen found in a loose block and numbered DAA-07-53 (Plate II, 10).

5.3.1.2. Description. The preserved fragment of plant is small, approximately $1 \mathrm{~cm}$ long and $1 \mathrm{~cm}$ wide. It consists of a $6 \mathrm{~mm}$ long

\section{Plate I.}

1. Spiny zosterophyll, general view of specimen 16-DAA-108; scale: $4 \mathrm{~mm}$.

2. Spiny zosterophyll, detail showing a spine in face view at arrow; 16-DAA-108; scale: $1 \mathrm{~mm}$.

Spiny zosterophyll, detail showing distribution of spines; note the wide base of spines in profile view and the helical arrangement of three consecutive spines at arrows; 12-DAA-99; scale: $1 \mathrm{~mm}$

Spiny zosterophyll, general view of specimen 12-DAA-99; scale: $2 \mathrm{~mm}$.

Leclercqia complexa, general view of specimen 3-DAA-44; scale: $2 \mathrm{~mm}$.

Leclercqia complexa, detail showing a microphyllous leaf in face view; note the four segments in the same plane; 3-DAA-44; scale: 1 mm.

Leclercqia complexa, detail showing a microphyllous leaf in profile view; note position of the lower segment at arrow; 3-DAA-44; scale: 1 mm.

Undetermined lycopsid, general view of specimen DAA-07-1; note the spiral arrangement of leaf bases; scale: $1 \mathrm{~cm}$.

Undetermined lycopsid, detail showing the rhomboidal leaf bases; note the thickening at the upper angle of the leaf base at arrow; DAA-07-1; scale: 1 mm.

Undetermined lycopsid, detail of the rhomboidal leaf bases under oblique light; note the central circular elevation at arrow; DAA-07-1; scale: 1 cm.

Undetermined lycopsid, latex cast of the surface of specimen DAA-07-1; scale: $1 \mathrm{~cm}$

Incertae sedis, general view of specimen 16-DAA-112; scale: 2 mm. 
and $0.4 \mathrm{~mm}$ wide axis bearing numerous ultimate appendages and showing narrow spines in its proximal part. This axis is complete, with both ends preserved. It is attached to a $0.6 \mathrm{~mm}$ wide and short portion of axis also covered with fine spines. The ultimate appendages are all sterile and apparently arranged in whorls (Plate II, 10, arrowhead), except distally where they may be produced helically. They measure 3.5 to $4.3 \mathrm{~mm}$ long and branch three to four times isotomously. Their tips are acute and recurved. Spines on the two preserved orders of axes are relatively long ( 0.7 to $0.8 \mathrm{~mm}$ ) (Plate II, 10 , arrow).

5.3.1.3. Interpretation. Termier and Termier (1950) did not mention such a type of plant. The general morphology of this specimen is comparable to that of the fourth order axes described in Anapaulia, a monospecific genus affiliated to the Iridopteridales and recorded thus far only from the Lower Member of the Campo Chico Formation (Givetian) in Venezuela (Berry and Edwards, 1996). Similarities between the distalmost parts of Anapaulia moodyi and the Moroccan specimen include the size of the different components, the morphology and arrangement of the ultimate appendages and the presence of long and narrow spines on all orders of axes. They correspond to some of the features listed by Berry and Edwards (1996) to characterize A. moodyi. The other specific characters of $A$. moodyi relate to the overall architecture of the plant and the morphology of the fertile parts. These characters are missing in our specimen. However, the similarities noted above are so obvious that we are confident in the affiliation of the Moroccan specimen to A. moodyi.

\subsection{Progymnosperms - Aneurophytales}

\subsubsection{Rellimia sp.}

See Gerrienne et al. (2010) for complete description and discussion.

5.4.1.1. Material. This taxon is represented by a single specimen numbered DAA 123 (Plate II, 5). It was collected from a loose block near the base of the section. The counterpart is missing.

5.4.1.2. Description and interpretation. The specimen consists of a $6.5 \mathrm{~cm}$ long fragment of axis bearing at least three large fertile organs. Its assignation to the aneurophytalean genus Rellimia is based on (i) the spiral arrangement of the fertile organs, (ii) their recurved shape; (iii) their branching pattern, with a proximal dichotomy (Plate II, 5 , arrow) followed by two orders of pinnate branches, and (iv) the shape of the sporangia.

\subsection{2. "Aneurophyton" maroccanum sensu Termier E Termier (1950)}

5.4.2.1. Material. Specimens attributed to this taxon have been found in all studied plant beds. Up to 80 fragments have been collected. They present a wide range of preservation from badly weathered red to brown impressions to black carbonaceous compressions. The description below is mainly based on specimen 10-DAA-80 (Plate II, 7) from plant bed 10, on specimens 11-DAA-84 (Plate II, 8) and DAA-07-6 from plant bed 11, and on specimen DAA-07-44 (Plate II, 9) found near plant bed 11 .

5.4.2.2. Description. Most specimens correspond to isolated portions of branches bearing helically arranged ultimate appendages (Plate II, $7,8)$. These branches are $2.5-5 \mathrm{~mm}$ wide, pseudomonopodial and straight. Their surface is ribbed. The ultimate appendages are up to $12 \mathrm{~mm}$ long and dichotomize isotomously three to four times (Plate II, 6-8). The first dichotomy occurs at, or very close to, the level of divergence from the axis (Plate II, 8 at arrow). Individual segments in the appendages may be relatively broad $(1.4-1.6 \mathrm{~mm})$, including those in distal position $(0.8-0.9 \mathrm{~mm})$ (Plate II, 7). The terminal segments are either straight or slightly recurved outwards (Plate II,
6). Some more complete specimens show two orders of axes (Plate II, 9 ). Branches are produced helically on the penultimate axes. They are borne singly and at a relatively wide angle on the supporting axis. Ultimate appendages are observed on some penultimate axes.

A few isolated specimens preserved as impressions consist of 0.5-0.7 $\mathrm{mm}$ wide axes dividing anisotomously and lacking epidermal outgrowth (Pl. II, Fig. 4). They resemble some high-order branches of "Aneurophyton" maroccanum showing distantly spaced ultimate appendages. Their assignation to this taxon is, however, uncertain.

5.4.2.3. Interpretation. The species "Aneurophyton" maroccanum was established by Termier and Termier (1950). The generic attribution of this plant has been questioned or even rejected (Schweitzer and Matten, 1982; Fairon-Demaret and Régnault, 1986). Termier and Termier (1950) did not give any diagnosis nor any clear description of the specimens but they provided numerous drawings. The specimens described here are totally consistent with the figures and are thus considered identical to "A." maroccanum sensu Termier and Termier.

The Moroccan plants which show a pseudomonopodial branching pattern and a helical arrangement of the branches are undoubtedly part of the euphyllophytes (Kenrick and Crane, 1997). A considerable increase of complexity is observed in this clade across the Devonian. In the basalmost euphyllophytes, as exemplified by a number of Psilophyton species, the stem has a zig-zag shape and produces dichotomizing lateral axes (Taylor et al., 2009). Pertica shows a sharper distinction between a straight stem and lateral branching systems that, despite their large size, remain highly determinate and branch either isotomously or anisotomously (Granoff et al., 1976). The more derived Aneurophytales reach a further level of architectural complexity. Lateral branches are strongly pseudomonopodial and show a higher growth potential. Dichotomizing ultimate appendages occur not only on the ultimate order of branches but also on other axes (Schweitzer and Matten, 1982; Beck and Wight, 1988; Dannenhoffer et al., 2007). The Moroccan specimens possess this latter set of derived characters. In addition, a permineralized portion of axis exhibiting stelar anatomy fully justifies comparison with the aneurophytalean progymnosperms.

Three genera of Aneurophytales are recognized from external morphology (Beck and Wight, 1988), Tetraxylopteris, Aneurophyton and Rellimia. Based on their branching patterns, the specimens from Dechra Aït Abdallah compare more favorably with Aneurophyton and Rellimia, which branch helically, than with Tetraxylopteris which branches decussately. Vegetative morphology of Aneurophyton and Rellimia is close. These two genera differ mainly by the morphology of their fertile organs and the vascular anatomy of their axes (Bonamo, 1977; Schweitzer and Matten, 1982; Beck and Wight, 1988). Apart from size differences, their vegetative morphology is considered as similar.

The available evidence concerning the vegetative body of these two genera, however, is equivocal. Schweitzer and Matten (1982) observed paired branches in German specimens of Aneurophyton and Rellimia whereas Dannenhoffer et al. (2007) described specimens of Rellimia from New York State producing single branches at nodes, like the Moroccan specimens. The full range of variation in the vegetative body of these two genera obviously requires more investigation (Beck and Wight, 1988).

Of special interest for this discussion is the fertile specimen referred to as Rellimia sp. from Dechra Aït Abdallah, albeit not in organic connection with any remains of the "Aneurophyton" maroccanum type. Interestingly also, Schweitzer and Matten (1982) described bud-like structures at the tip of ultimate branches in $A$. germanicum that are similar to the so-called "Cordaianthus" remains reported by Termier and Termier (1950) (compare Schweitzer and Matten, 1982, Text-Fig. 6 and Termier and Termier, 1950, Pl.Texte 6 Fig. 55). 
In conclusion, the Moroccan specimens are close to Aneurophyton and Rellimia. However, due to the limited understanding of the vegetative morphology of these taxa and the lack of any fertile organs connected to the Moroccan remains, a firm assignation of these fossils to either Aneurophyton, Rellimia, or a new genus is premature, hence we designate them "Aneurophyton" maroccanum.

\subsection{Incertae sedis}

\subsubsection{Psilophytites $s p$.}

5.5.1.1. Material. A single specimen of this plant has been recovered as a poorly preserved impression (Plate II, 1-2). It originates from bed 2 at the top of the section (Fig. 2) and is numbered 2-DAA-19.

5.5.1.2. Description. The specimen is a $10 \mathrm{~cm}$ long fragment of narrow axis branched through slightly anisotomous dichotomies and whose surface is spiny. Two dichotomies are visible on the rock surface (labeled 1 and 2 on Plate II, 1). A third one may have occurred in a different plane (labeled 3 on Plate II, 1). The axis is $2 \mathrm{~mm}$ wide and the length between branching points 1 and 2 is $3.3 \mathrm{~cm}$. Branching angles at points 1 and 2 are about $30^{\circ}$. The small emergences at the surface of the specimen are not contiguous. Their arrangement, whether regular or not, is uncertain. Individual emergences measure between 0.5 and $0.9 \mathrm{~mm}$ in length. Their tip is badly preserved. Their base ranges from 0.2 to $0.3 \mathrm{~mm}$ in width (Plate II, 2) and may be slightly decurrent on the axis.

5.5.1.3. Interpretation. Termier and Termier (1950) would have assigned this type of axis to Psilophyton princeps. Today, the lack of counterpart and absence of fertile organs prevent such a taxonomic identification. Psilophytites was created for vegetative axes of various affinities that, like the specimen described here, present undivided spines scattered on the surface (Høeg, 1952; Banks, 1975; Gerrienne, 1992). The specimen from Dechra Ait Abdallah differs from Psilophytites rectissimus from the Lower Devonian of Norway which is larger in diameter and branches rarely (Høeg, 1967; Gerrienne, 1992). Psilophytites gileppensis from the Lower Devonian of Belgium is represented by axes closer in dimension but differs in dichotomies that are more clearly anisotomous, by longer and denser emergences and by the consistent occurrence of a dwarf spiny axis associated with the dichotomies (Gerrienne, 1992). Fairon-Demaret and Régnault (1986) reported a large number of spiny axes, some dichotomously branched, in the Chabat Jenanat Formation at Imouzzer-du-Kandar (Central Morocco). Beds are presumed to be upper Emsian or Eifelian in age. The specimen illustrated on their Pl. 1 Fig. 5 branches once and compares to that from Dechra Ait Abdallah in its diameter and branch divergence angle. The shape and size of the emergences are unknown.

\subsubsection{Hostinella sp.}

5.5.2.1. Material. This plant type is represented by two specimens, 2 DAA-5 (Plate II, 3), collected in the same bed 2 as the specimen of Psilophytites described above, and DAA-07-40 from the highest sampled bed (Fig. 2).

The two specimens consist of very narrow fragments of naked axes which branch through almost equal dichotomies separated by relatively long internodes. Axis diameter is about $1 \mathrm{~mm}$ at all levels in both specimens. Specimen 2-DAA-5 is a $5 \mathrm{~cm}$ long fragment of axis showing three dichotomies on the rock surface. The angles between daughter branches are about $45^{\circ}$. Specimen DAA07-40, slightly longer $(8 \mathrm{~cm})$, shows two dichotomies in a plane different from that of the rock surface.

5.5.2.2. Interpretation. Small naked dichotomizing axes lacking fertile parts are common among Emsian to Eifelian sediments. Such axes are referable to Hostinella (Potonié and Bernard, 1904), a morphogenus corresponding to axes of various morphologies that may belong to a large range of taxa including the Zosterophyllopsida and the basal euphyllophytes (Fairon-Demaret, 1967). The distinctive morphology of the Moroccan axes that are characterized by slender axes and sparse branches departing at narrow angle, recalls Hostinella specimens of presumed Lower Devonian age from Röragen, Norway (Halle, 1916; Pl. 2, Fig. 9). Another comparable specimen is the one numbered PA 1101 collected in Mimerdalen, Spitsbergen, from a Devonian outcrop of uncertain age, and designated as "Psilophyte?" by Høeg (1942, Pl. LVI, Fig. 12). It consists of a $5 \mathrm{~cm}$ long and very slender axis that bifurcates twice isotomously, with a distance of $2.5 \mathrm{~cm}$ between the two branching points.

\subsubsection{Undetermined axes}

5.5.3.1. Material. One specimen numbered 16-DAA-112, coming from bed 16 , represents this morphotype (Plate I, 12).

5.5.3.2. Description. It consists of a $2-3 \mathrm{~mm}$ wide axis bearing spirally arranged lateral units (Plate I, 12). The axis is devoid of epidermal outgrowths. Lateral units are produced in pairs but are always broken after 1 or $2 \mathrm{~mm}$.

5.5.3.3. Interpretation. The identification of this badly preserved and fragmentary specimen is not possible. More material would be necessary.

\subsubsection{Carbon accumulation}

5.5.4.1. Material. Two specimens of this structure have been found in plant bed 3. They are respectively numbered 3-DAA-37 and DAA-0745 (Plate II, 11).

5.5.4.2. Description. This structure corresponds to a group of semicircular organs (Plate II, 11). They do not show any characteristic feature at surface except preservation cracks.

5.5.4.3. Interpretation. We interpret these remains as representing a fortuitous accumulation of organic matter. We suspect that the specimen called "Archaeopteris"? rotundifolia by Termier and Termier (1950) was a comparable structure.

\section{Discussion}

\subsection{Significance of plant remain abundance in the allochthonous deposits of Dechra Aït Abdallah}

Fossil plant remains are particularly common at the Lachaq section (Termier and Termier, 1950; this work). Despite variability in abundance and preservation state, they have been collected throughout the whole section in nearly all silty beds. They are often represented by small fragments suggesting a transport over some distance before being deposited. However, "Aneurophyton" maroccanum is generally more completely preserved than any other remains. This plant is also by far the most abundant when considering the whole section at Lachaq. About 55\% of the specimens can be confidently assigned to this taxon. As discussed by Cressler (2006), the occurrence of locally concentrated and well preserved remains of a plant as well as scattered fragmentary remains throughout the deposit indicates that this plant was widespread in the surrounding landscape. It is thus suggested that "A." maroccanum grew on or near the shoreline or fluviatile systems feeding into the sea.

One other peculiar aspect of this assemblage is, with the exception of one single specimen of Rellimia, the nearly total absence of fertile parts among the collected fossils. The marine deposits, transportation and subsequent sorting of plant remains could have isolated the small delicate sporangia from their parent plants. However, tiny fragile 


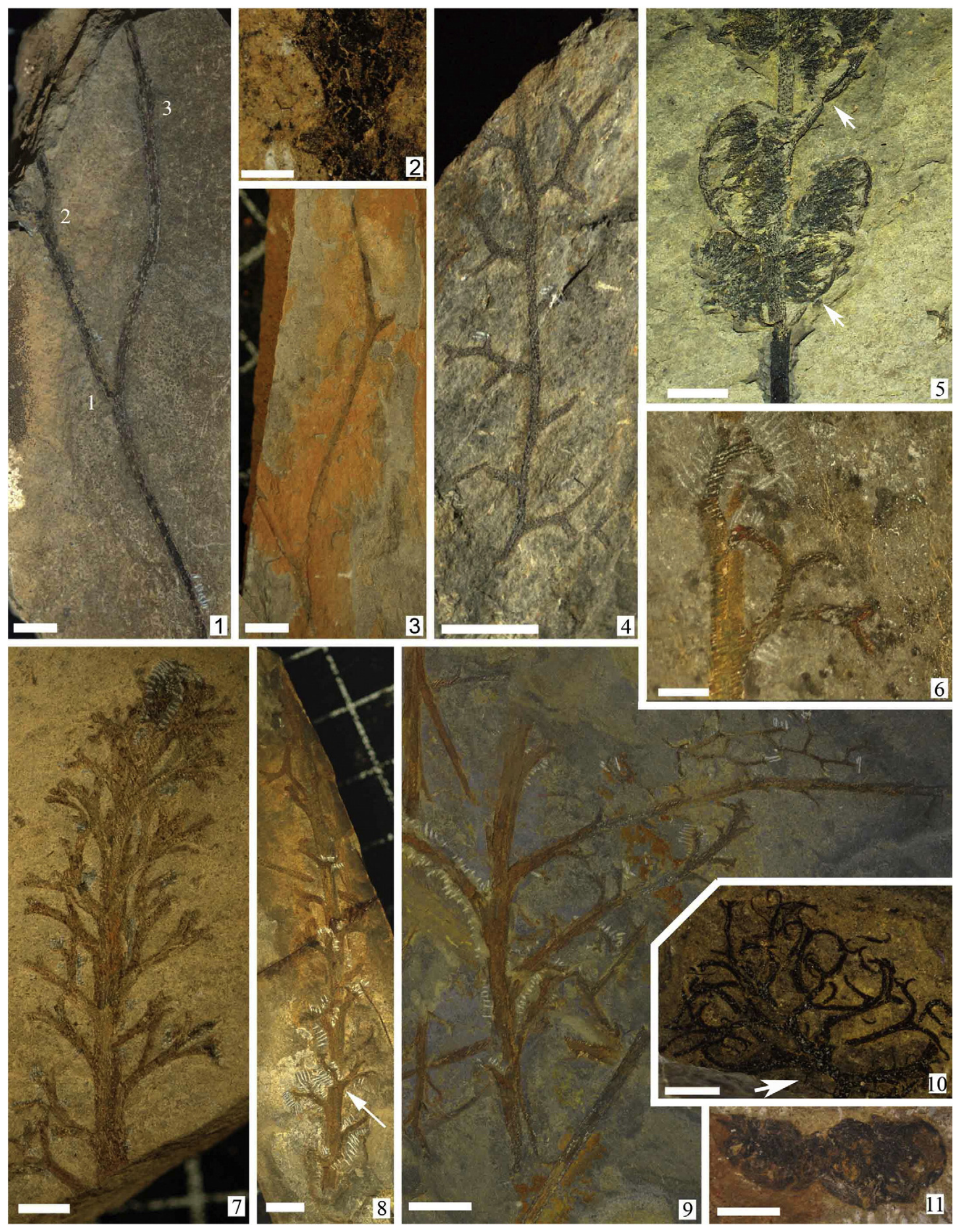


Table 1

Updated taxonomic composition of the Dechra Ait Abdallah floral assemblage. Comparison with Termier and Termier's (1950) floral list.

\begin{tabular}{ll}
\hline Dechra Aït Abdallah floral list & \\
\hline This work & Termier and Termier (1950) \\
\hline Spiny zosterophyll & Psilophyton princeps (pro parte) \\
Leclercqia complexa & Incertae sedis \\
Undet. Lycopsida & Absent \\
Anapaulia moodyi & Absent \\
Rellimia sp. & Absent \\
"Aneurophyton" maroccanum & Aneurophyton maroccanum \\
"Aneurophyton" maroccanum? & Cordaianthus devonicus \\
Psilophytites sp. & Psilophyton princeps (pro parte) \\
Hostinella sp. & Asteroxylon elberfeldense \\
Undet. axis & Hyenia cf. elegans \\
Carbon accumulation & "Archaeopteris"? rotundifolia \\
$?$ & Scougouphyton abdallahense \\
\hline
\end{tabular}

ultimate appendages either in connection or dispersed occur throughout the section. Two other, possibly complementary, hypotheses are thus considered to account for the lack of fertile organs in conjunction with the presence of delicate plant organs.

The first hypothesis is linked to the climatic conditions of northern Africa in the Middle Devonian. As testified by the limestone microalgal content as well as the general reef environment of the surrounding paleoregion, warm climatic conditions most probably prevailed during deposition (Termier and Termier, 1972; Termier et al., 1977; Hoepffner et al., 2005). Plant remains are found in silty layers interbedded in the limestone deposits. They correspond to fluvial pulses likely resulting from wet events (Grobe, 1997). This suggests that the climate was seasonal with relatively long dry and warm periods interrupted by short but intense rain events. They washed out the surrounding landscape transporting the plant remains as well as the silty matrix. Recurrence of these events outside of the reproductive season would explain the lack of fertile parts in the assemblage.

The second hypothesis is based on the "Competitor-Stress tolerator-Ruderal" (CSR) ecological strategies formulated by Grime (1977) and used by Hotton et al. (2001) to interpret the patterns of plant distribution in an Emsian landscape at Gaspé Bay, Canada. Plants occupying stressful habitats at Gaspé show traits suggestive of extended vegetative growth, clonal reproduction and low sporangial production. In contrast, pioneer plants like the euphyllophyte Psilophyton invest much more in fertile organs to achieve rapid and abundant sexual reproduction. It is possible that the lack of fertile organs in the plant remains from Dechra Ait Abdallah was also related, in part, to their life cycle and ability to cope with stressful environment. Interestingly, the only fertile organ that we collected in this locality has euphyllophytic affinities.

\subsection{Diversity of the new plant assemblage from Dechra Ait Abdallah}

The Dechra Aït Abdallah plant assemblage has a relative low diversity, but all major groups of late Early Devonian and Middle
Devonian age are represented, i.e. the Zosterophyllopsida, Lycopsida, Cladoxylopsida, aneurophytalean Progymnospermopsida, and possibly some basal euphyllophytes. Table 1 summarizes the new floral list and compares it to that provided by Termier and Termier (1950).

A large number of plant remains from the new collection are morphologically similar to those illustrated by Termier and Termier (1950), but are assigned to different taxa in the present paper. The lack of fertile parts makes taxonomic identifications difficult: groups such as zosterophylls and basal euphyllophytes show morphological convergences and are difficult to discriminate satisfactorily. We used fossil genera such as Hostinella for specimens similar to those assigned to Asteroxylon elberfeldense by Termier and Termier (1950), and Psilophytites and "spiny zosterophyll" for remains similar to their Psilophyton princeps. This by no means refutes the possibility that Psilophyton-type plants inhabited the region of Dechra Aït Abdallah in the Middle Devonian. However, without any corresponding fertile organs, the available fossil record does not permit to account for their occurrence with certainty. The illustrated specimens of Hyenia cf. elegans provided by Termier and Termier (1950) do not show any discriminating feature justifying their assignation to Hyenia. In addition, the new plant collection does not include any remain assignable to Hyenia. The socalled "Archaeopteris"? rotundifolia of Termier and Termier (1950) probably refers to isolated carbon accumulation. In contrast, a number of leafy axes that would have been referred to as Incertae sedis by Termier and Termier (1950) have been shown here to correspond to the well-known species Leclercqia complexa.

Our description of the remains of "Aneurophyton" maroccanum, complementing that of Termier and Termier (1950), justifies their assignment to the Aneurophytales but leaves open the question of their generic affinities. Termier and Termier (1950, Planche-texte 6, Figs. 51 and 52) erected the new taxon Scougouphyton abdallahense for stems interpreted as bearing long grass-like leaves and axillary branches, some terminated by sporangia. This description does not correspond to any of the fossils we collected. Based on their drawings, some specimens share superficial characters with "A." maroccanum. Ultimate appendages of Scougouphyton, however, are simpler, less divided and more scattered than in the latter species. A detailed study of "A." maroccanum is presently in progress.

The new collection includes three plants that do not correspond to any fossil reported by Termier and Termier (1950). One is represented by lycopsid stems of uncertain affinities covered by a dense pattern of small rhomboidal leaf bases. The two others are Anapaulia moodyi, of iridopteridalean affinities, and Rellimia sp., an aneurophytalean progymnosperm.

\subsection{Palaeobiogeographic and stratigraphic significances of the new plant assemblage from Dechra Aït Abdallah}

Information provided by the tentaculites suggest a possible late Emsian age for the studied flora (Gerrienne et al., 2010), although that provided by the trilobites suggest an Eifelian age (Feist, pers. com.). The combined stratigraphic ranges of Leclercqia, Rellimia, Aneurophyton and Anapaulia indicate that a Givetian age is more likely (Fig. 5). Before this work, Anapaulia, however, had been reported only from the Givetian of

\section{Plate II.}

Psilophytites sp., general view of specimen 2-DAA-19; scale: $5 \mathrm{~mm}$.

Psilophytites sp., detail showing two slightly decurrent spines; 2-DAA-19; scale: $1 \mathrm{~mm}$

Hostinella sp., general view of specimen 2-DAA-5, scale: $5 \mathrm{~mm}$.

general view of specimen 5-DAA-62 resembling some high-order axes of "Aneurophyton" maroccanum with distantly spaced ultimate appendages; scale 5 mm.

Rellimia sp., proximal dichotomy of a fertile organ at arrow; specimen DAA-123; scale: $8 \mathrm{~mm}$.

"Aneurophyton" maroccanum, ultimate appendage; specimen 10-DAA-80; scale: $1 \mathrm{~cm}$.

"Aneurophyton" maroccanum, general view of specimen 10-DAA-80; scale: $1 \mathrm{~cm}$.

"Aneurophyton" maroccanum, general view of specimen 11-DAA-84; scale: $1 \mathrm{~cm}$.

"Aneurophyton" maroccanum, general view of specimen DAA-07-44; scale: $2 \mathrm{~cm}$.

Anapaulia moodyi, general view of specimen DAA-07-53; spine at arrow; scale: $2 \mathrm{~mm}$.

Carbon accumulation, specimen DAA-07-45; scale: $1 \mathrm{~cm}$. 


\begin{tabular}{|c|c|c|c|c|c|c|c|}
\hline & \multicolumn{7}{|c|}{ Devonian } \\
\hline & \multicolumn{3}{|c|}{ Lower } & \multicolumn{2}{|c|}{ Middle } & \multicolumn{2}{|c|}{ Upper } \\
\hline & Lochkovian & Pragian & Emsian & Eifelian & Givetian & Frasnian & Famennian \\
\hline \multicolumn{8}{|l|}{ Psilophyton } \\
\hline Leclercqia & & & & & & & \\
\hline Rellimia & & & & & & & \\
\hline Aneurophyton & & & & & & & \\
\hline Anapaulia & & & & & & & \\
\hline
\end{tabular}

Fig. 5. Stratigraphic distribution of the genera reported from Dechra Aït Abdallah. The presence of Psilophyton and Sawdonia is suspected but not ascertained.

Venezuela (Berry and Edwards, 1996). Its stratigraphic range is therefore far from being completely understood. If the Givetian age constraint brought by the occurrence of Anapaulia is removed, then an Eifelian age cannot be ruled out, as originally assumed by Termier and Termier (1950). Given the total evidence brought by the fossils we collected in the plant beds from Dechra Ait Abdallah, we will refer the flora as Middle Devonian considering that to date it would be unwise to be more precise about its age.

Devonian palaeobiogeographic considerations are difficult to address particularly for the first half of this period (Raymond, 1987). The discrepancy between our knowledge of fossil plant assemblages from Gondwana and from the other paleocontinents is enormous. Assessing the cosmopolitan/provincial character of the flora from Dechra Ait Abdallah is uncertain because of its low diversity and the uncertainties concerning the generic affinities of some taxa. It is noteworthy, however, that this flora comprises individual taxa characterized by a cosmopolitan distribution. They are Leclercqia complexa and possibly also, the spiny zosterophyll. Alongside these two plants, Rellimia is another taxon with a widespread, albeit not cosmopolitan, distribution. The single occurrence of Rellimia in Gondwana is in Morocco (Gerrienne et al., 2010). In contrast, several plants in this assemblage appear to be more limited paleogeographically and, up to now, restricted to Gondwana. It is the case for Anapaulia moodyi, and possibly also for "Aneurophyton" maroccanum and the undetermined lycopsid.

If we consider the assemblage as a whole, the flora of Dechra Ait Abdallah shows some similarities with the Middle Devonian floras from the European part of Laurussia such as Germany and Belgium. However, the occurrence of taxa thus far known only in Gondwana suggests that this paleoregion could represent a zone of exchange between floras of Gondwana and Laurussia, implying a paleogeographical proximity of these paleocontinents. Gerrienne et al. (1999) came to the same conclusions when they studied the Emsian assemblage from Jbel Ben Aarab (Morocco).

\section{Acknowledgments}

We thank the Ministère de l'Energie et des Mines (Rabat, Morocco) for the issue of working permits and the permissions to export fossil material. We also thank Mr. Mohammed Mourchid for permission to collect fossils in his property at Dechra Ait Abdallah. We are indebted to Raimund Feist and Catherine Girard (Institut des Sciences de l'Evolution, Montpellier) who respectively identified the trilobites and prepared the material in order to find conodonts. We thank Danielle Lacoeuilhe (Université de Cergy-Pontoise) and Pascal Barrier (Institut Polytechnique LaSalle Beauvais) who helped in our effort to find the Termier's collections of fossil plants. Jobst Wendt and Libuse Rammerstorfer (University of Tübingen) are acknowledged for their help in finding Bohn's and Grobe's master theses. This work was supported in part by the ANR project "ACCRO-EARTH" (no. ANR-2006-BLAN-347) which provided an eight month fellowship to Cyrille Prestianni and by the ANR project "TERRES" (no. ANR-2010-BLAN-607). P. Gerrienne is a F.R.S.-FNRS Research Associate. AMAP (Botany and Computational
Plant Architecture) is a joint Research Unit which associates CIRAD (UMR 51), CNRS (UMR5120), INRA (UMR931), IRD(R123) and Université Montpellier 2 (UM27) (http://amap.cirad.fr/).

\section{References}

Alberti, G.K.B., 1970. Trilobites des jüngeren Siluriums sowie des Unter und Mitteldevons II. Abhandlungen der Senckenberg Gessellschaft fur Naturforschung 525, 1-233.

Banks, H.P., 1975. Reclassification of Psilophyta. Taxon 24, 401-413.

Banks, H.P., Bonamo, P.M., Grierson, J.D., 1972. Leclercqia complexa gen. et sp. nov., a new lycopod from the late Middle Devonian of eastern New York. Review of Palaeobotany and Palynology 14, 19-40.

Beck, C.B., Wight, D.C., 1988. Progymnosperms. In: Beck, C.B. (Ed.), Origin and Evolution of Gymnosperms. Columbia University Press, New York, pp. 1-84.

Berry, C.M., 1994. First record of the Devonian lycophyte Leclercqia from South America. Geological Magazine 131, 269-272.

Berry, C.M., 1996. Diversity and distribution of Devonian Protolepidodendrales (Lycopsida). Paleobotanist 45, 209-216.

Berry, C.M., Edwards, D., 1996. Anapaulia moodyi gen. et sp. nov.: a probable iridopteridalean compression fossil from the Devonian of Western Venezuela. Review of Palaeobotany and Palynology 93, 127-145.

Berry, C.M., Morel, E., Mojica, J., Villarroel, C., 2000. Devonian plants from Colombia, with discussion of their geological and palaeogeographical context. Geological Magazine 137, 257-268.

Bohn, U., 1993. Geologie des südlichen Teils der Region Dchar-Ait-Abdallah (östliches Zentral-Marokko): Stratigraphie, Tektonik, Maturität und petrologische Untersuchungen an Magmatiten. Diplomarbeit Tübingen Universität, Tübingen. $82 \mathrm{pp}$.

Bonamo, P.M., 1977. Rellimia thomsonii (Progymnospermopsida) from the Middle Devonian of New York state. American Journal of Botany 64, 1272-1285.

Bonamo, P.M., Banks, H.P., Grierson, J.D., 1988. Leclercqia, Haskinsia, and the role of leaves in delineation of Devonian lycopod genera. Botanical Gazette 149, 222-239.

Bouabdelli, M., Cailleux, Y., Hoepffner, C., Michard, A., Pique, A., 1989. Le bassin dinantien d'Azrou et l'évolution de sa déformation hercynienne (Méséta marocaine nord-orientale). Notes et Mémoires du Service Géologique du Maroc 335, 221-227.

Cascales-Miñana, B., Muñoz-Bertomeu, J., Ros, R., Segura, J., 2010. Trends and patterns in the evolution of vascular plants: macroevolutionary implications of a multilevel taxonomic analyses. Lethaia $43,545-557$.

Chaloner, W.G., Sheerin, A., 1979. Devonian macrofloras. In: House, M.R., Scrutton, C.T. Bassett, M.G. (Eds.), The Devonian System: Palaeontological Society, London, Special Papers in Palaeontology, 23, pp. 145-161.

Cressler III, W.L., 2006. Plant palaeoecology of the Late Devonian Red Hill locality, northcentral Pennsylvania, an Archaeopteris-dominated wetland plant community and early tetrapod site. In: Greb, S.F., DiMichele, W.A. (Eds.), Wetlands Through Time: Geological Society of America, Boulder, Colorado, Special Papers, 399, pp. 79-102.

Dannenhoffer, J.M., Stein, W., Bonamo, P.M., 2007. The primary body of Rellimia thomsonii: integrated perspective based on organically connected specimens. International Journal of Plant Sciences 168, 491-506.

Dawson, J.W., 1861. On the pre-Carboniferous flora of New Brunswick, Maine and Eastern Canada. Canadian Naturalist 6, 161-181.

Edwards, D., Berry, C., 1991. Silurian and Devonian. In: Cleal, C.J. (Ed.), Plant Fossils in Geological Investigation. Ellis Horwood, New York, pp. 117-153.

Edwards, D., Fairon-Demaret, M., Berry, C.M., 2000. Plant megafossils in Devonian stratigraphy: a progress report. Courier Forschungsinstitut Senckenberg 220, 25-37.

Edwards, D., Poiré, D.G., Morel, E.M., Cingolani, C.A., 2009. Plant assemblages from SW Gondwana: further evidence for high-latitude vegetation in the Devonian of Argentina. In: Bassett, M.G. (Ed.), Early Palaeozoic Peri-Gondwana Terranes: New Insights from Tectonics and Biogeography: Geological Society, London, Special Publications, 325, pp. 233-255.

Faik, F., 1988. Le Paléozoïque de la Région de Mrirt (Est du Maroc Central): évolution stratigraphique et structurale. Thèse de $3^{\text {ème }}$ cycle, Université Paul Sabatier de Toulouse (Sciences), Toulouse. 233 pp.

Fairon-Demaret, M., 1967. L'Asteroxylon elberfeldense Kraüsel et Weyland porte-t-il des axes terminaux du type Hostimella hostimensis Potonié et Bernard? Annales de la Société Géologique de Belgique 10,1-30.

Fairon-Demaret, M., Régnault, S., 1986. Macroflores dévoniennes dans le Nord du Maroc (Boutonnière d'Imouzzer-du-Kandar, Sud de Fès). Etude paléobotanique. 
Implications stratigraphiques et paléogéographiques. Annales de la Société Géologique de Belgique 109, 499-513.

Fairon-Demaret, M., Hilton, J., Berry, C.M., 1999. Surface preparation of macrofossils (dégagement). In: Jones, T.P., Rowe, N.P. (Eds.), Fossil Plants and Spores. Modern Techniques. Geological Society, London, pp. 33-35.

Frenguelli, J., 1954. Plantas devónicas de la Quebrada de la Charnela en la precordillera de San Juan. Notas del Museo La Plata 17, 359-376.

Gensel, P.G., Albright, V.M., 2006. Leclercqia complexa from the Early Devonian (Emsian) of northern New Brunswick, Canada. Review of Palaeobotany and Palynology 142, 103-121.

Gensel, P.G., Andrews, H.N., 1984. Plant Life in the Devonian. Praeger, New York, New York. 380 pp.

Gensel, P.G., Kasper, A.E.J., 2005. A new species of the Devonian lycopod genus, Leclercqia, from the Emsian of New Brunswick, Canada. Review of Palaeobotany and Palynology 137, 105-123.

Gensel, P.G., Andrews, H.N., Forbes, W.H., 1975. A new species of Sawdonia with notes on the origin of microphylls and lateral sporangia. Botanical Gazette 136, 60-62.

Gerrienne, P., 1992. Psilophytites gileppensis nov. sp., une plante épineuse du Dévonien Inférieur du bord sud du Synclinorium de Verviers (Belgique). Geobios 25, 439-447.

Gerrienne, P., 1993. Inventaire des végétaux éodévoniens de Belgique. Annales de la Société Géologique de Belgique 116, 105-117.

Gerrienne, P., 1996a. The fossil plants from the Lower Devonian of Marchin (northern margin of Dinant Synclinorium, Belgium). IV. Odonax borealis gen. et spec. nov. Review of Palaeobotany and Palynology 93, 89-106.

Gerrienne, P., 1996b. Contribution à l'étude paléobotanique du Dévonien inférieur de la Belgique: les genres nouveaux Ensivalia et Faironella. Publication de la Classe des Sciences, Collection in $4^{\circ}$, 3è sér. Académie Royale de Belgique, pp. 1-94.

Gerrienne, P., Fairon-Demaret, M., Galtier, J., Lardeux, H., Meyer-Berthaud, Régnault, S. Steemans, P., 1999. Plants associated with tentaculites in a new Early Devonian locality from Morocco. Abhandlungen der Geologischen Bundesanstalt A 54, 323-335.

Gerrienne, P., Meyer-Berthaud, B., Lardeux, H., Régnault, S., 2010. First record of Rellimia Leclercq \& Bonamo (Aneurophytales) from Gondwana, with comments on earliest lignophytes. In: Vecoli, M., Clément, G., Meyer-Berthaud, B. (Eds.), The Terrestrialization Process: Modelling Complex Interactions at the Biosphere-Geosphere Interface: Geological Society, London, Special Publications, 339, pp. 81-92.

Granoff, J.A., Gensel, P.G., Andrews Jr., H.N., 1976. A new species of Pertica from the Devonian of eastern Canada. Palaeontographica 155B, 119-128.

Greb, S.F., DiMichele, W.A., Gastaldo, R.A., 2006. Evolution and importance of wetlands in earth history. In: Greb, S.F., DiMichele, W.A. (Eds.), Wetlands Through Time: Geological Society of America, Boulder, Colorado. Special Papers, 399, pp. 1-40.

Grierson, J.D., Banks, H.P., 1963. Lycopods of the Devonian of New York State Paleontographica Americana 4, 220-295.

Grierson, J.D., Hueber, F.M., 1968. Devonian lycopods from northern New Brunswick. In: Oswald, D.H. (Ed.), International Symposium on the Devonian System. Alberta Society of Petroleum Geologists, Calgary, Alta., Canada, pp. 823-836

Grime, J.P., 1977. Evidence for the existence of three primary strategies in plants and its relevance to ecological and evolutionary theory. American Naturalist 111, 1169-1194.

Grobe, M., 1993. Stratigraphie, Fazies, Tektonik und Maturität des Paläozoikums von Dchar-Aït-Abdallah (östliches Zentral-Marokko), unter besonderer Berücksichtigung der faziellen Entwicklung des Mittel- und Oberdevons. Diplomarbeit Tübingen Universität, Tübingen. $104 \mathrm{pp}$.

Grobe, M., 1997. The allochthonous Devonian units of Dchar-Aït-Abdallah, southeastern Meseta, east-central Morocco: a facies model. Gaea heidelbergensis 3, 149.

Gutak, J.M., Antonova, V.A., Ruban, D.R., 2010. Diversity and richness of the Devonian terrestrial plants in the Southeastern Mountainous Altay (Southern Siberia): regional versus global patterns. Palaeogeography, Palaeoclimatology, Palaeoecology 299, 240-249.

Halle, T.G., 1916. Lower Devonian plants from Röragen in Norway. Kunkliga Svenska Vetenskapsakademiens Handlingar 57, 3-46.

Høeg, O.A., 1942. The Downtonian and Devonian flora of Spitzbergen. Norges Svalbard-og Ishavs-Undersøkelser. Skrifter 83, 1-229.

Høeg, O.A., 1952. Psilophytites, a new form genus of Devonian plants. The Palaeobotanist 1 , 212-214.

Høeg, O.A., 1967. Psilophyta. In: Bourreau, E. (Ed.), Traité de Palaléobotanique, 2. Masson \& Cie, Paris, pp. 191-433.

Hoepffner, C., Soulaimani, A., Piqué, A., 2005. The Moroccan Hercynides. Journal of African Earth Sciences 43, 144-165.

Hotton, C.L., Hueber, F.M., Griffing, D.H., Bridge, J.S., 2001. Early terrestrial environments: an example from the Emsian of Gaspé, Canada. In: Gensel, P.G., Edwards, D. (Eds.), Plants Invade the Land: Evolutionary and Environmental Perspectives. Colombia University Press, New York, pp. 179-203.

Hueber, F.M., 1971. Sawdonia ornata: a new name for Psilophyton princeps var. ornatum. Taxon 20, 641-642.

Jurina, A.L., 1988. The Middle and Late Devonian floras of northern Eurasia Transactions of the Palaeontological Institute 220, 1-176.

Kenrick, P., Crane, P.R., 1997. The Origin and Early Diversification of Land Plants. A Cladistic Study. Smithsonian Institution Press, Washington. $441 \mathrm{pp}$.

Kräusel, R., Dolianiti, E., 1957. Restos vegetais das camadas Picos, Devoniano Inferior do Piauí. Boletim Divisão de Geologia e Mineralogia 173, 3-19.
Lejal-Nicol, A., 1975. Sur la paléoflore du Dévonien Moyen et Supérieur de la Lybie. Bulletin de la Société d'Histoire Naturelle d'Afrique du Nord 66, 61-95.

Lejal-Nicol, A., Massa, D., 1980. Sur des végétaux du Dévonien Inférieur de la Lybie. Review of Palaeobotany and Palynology 29, 221-239.

Lemoigne, Y., 1967. Reconnaissance paléobotanique dans le Sahara occidental (Région de Tindouf et Gara-Djebilet). Annales de la Société Géologique du Nord 87, 31-38.

Lemoigne, Y., 1982. Le genre Leptophloeum Dawson, 1862 du Dévonien. Geobios 1, 33-41.

Li, C.S., Edwards, D., 1997. A new microphyllous plant from the Lower Devonian of Yunnan Province, China. American Journal of Botany 84, 1441-1448.

Li, X.-X., Dou, Y.-W., Sun, Z.-H., 1986. The genus Leptophloeum Dawson based on a recent study of new material from the Junggar Basin, Xinjiang. Acta Palaeontologica Sinica 25, 350-379.

Matte, P., 2001. The Variscan collage and orogeny (480-290 Ma) and the tectonic definition of the Armorica microplate: a review. Terra Nova 13, 122-128.

Meyer-Berthaud, B., Fairon-Demaret, M., Steemans, P., Talent, J., Gerrienne, P., 2003. The plant Leclercqia (Lycopsida) in Gondwana: implications for reconstructing Middle Devonian palaeogeography. Geological Magazine 140, 119-130.

Michard, A., 1976. Eléments de géologie marocaine. Notes et Mémoires du Service de la Carte Géologique du Maroc. Rabat 252, 1-408.

Potonié, H., Bernard, C., 1904. Flore dévonienne de l'étage H de Barrande. Supplément of Système Silurien du centre de la Bohème, Barrande, Prague. 68 pp.

Raymond, A., 1987. Paleogeographic distribution of Early Devonian plant traits. Palaios $2,113-132$.

Raymond, A., Metz, C., 1995. Laurussian land-plant diversity during the Silurian and Devonian: mass extinction, sampling bias, or both? Paleobiology 21, 74-91.

Raymond, A., Parker, W.C., Barrett, S.F., 1985. Early Devonian phytogeography. In: Tiffney, B.H. (Ed.), Geological Factors and the Evolution of Plants. Yale University Press, Yale, pp. 129-168.

Remy, W., Schultka, S., Hass, H., 1986. Anisophyton gothani nov. gen., nov. spec., und Hinweise zur Stratigraphie der Südlichen Wilbringhaüser Scholle. Argumenta Palaeobotanica 7, 79-107

Schweitzer, H.J., Matten, L.C., 1982. Aneurophyton germanicum and Protolepidodendron thomsonii from the Middle Devonian of Germany. Palaeontographica 184B, 65-106.

Scotese, C.R., 1999. Digital Paleogeographic Map Archive on CD-Rom. Paleomap Project, Arlington, TX.

Scotese, C.R., McKerrow, W.S., 1990. Revised world maps and introduction. In: McKerrow, W.S., Scotese, C.R. (Eds.), Palaeozoic Paleogeography and Biogeography: Geological Society, London, Memoir, 12, pp. 1-21.

Stockmans, F., 1940. Végétaux éodévoniens de la Belgique. Mémoires du Musée Royal d'Histoire Naturelle de Belgique 23, 1-90.

Streel, M., Fairon-Demaret, M., Gerrienne, P., Loboziak, S., Steemans, P., 1990a. Lower and Middle miospore-based stratigraphy in Libya and its relation to the megaflora and faunas. Review of Palaeobotany and Palynology 66, 229-242.

Streel, M., Fairon-Demaret, M., Loboziak, S., 1990b. Givetian-Frasnian phytogeography of Euramerica and western Gondwana based on miospore distribution. In: McKerrow, W.S., Scotese, C.R. (Eds.), Palaeozoic Palaeogeography and Biogeography: Geological Society, London, Memoir, 12, pp. 291-296.

Streel, M., Caputo, M.V., Loboziak, S., Melo, J.H.G., 2000. Late Frasnian-Famennian climates based on palynomorph analyses and the question of the Late Devonian glaciations. Earth-Science Reviews 52, 121-173.

Sze, H.C., 1952. Upper Devonian plants from China. Scientia Sinica 1, 166-192.

Taylor, T.N., Taylor, E., Krings, M., 2009. Paleobotany: The Biology and Evolution of Fossil Plants, Second Edition. Academic Press, Burlington. 1230 pp.

Termier, H., Termier, G., 1947. Découverte de Psilophytinées dans l'Eifélien du Maroc Central. Compte Rendus semestriel de la Société Géologique de France 14, 284

Termier, H., Termier, G., 1950. La flore eifelienne de Dechra Aït Abdallah (Maroc Central). Bulletin de la Société Géologique de France 20, 197-224.

Termier, H., Termier, G., 1970. Sur la géologie de la région de Dchar-Aït-Abdallah (Maroc Central). Comptes Rendus de l'Académie des Sciences de Paris, série D 271, 1612-1613.

Termier, H., Termier, G., 1971. Ecologie et paléogéographie, au Dévonien sup. de Dchar-Aït-Abdallah. Comptes Rendus de l'Académie des Sciences de Paris, série D, 273, pp. 55-58.

Termier, H., Termier, G., 1972. Le rôle des algues calcaires dans la sédimentation de Dchar-Aït-Abdallah (Maroc central). Geobios 5 (2), 151-156.

Termier, H., Termier, G., 1973. Un biotope à Ptérinopectinidés dans le Dévonien moyen de Dchar-Aït-Abdallah (Maroc central). Haliotis 4, 195-201.

Termier, H., Termier, G., Vachard, D., 1975. Recherches micro-paléontologiques dans le paléozoïque supérieur du Maroc central. Cahier de micro-paléontologie, 4. C.N.R.S, p. 99.

Termier, H., Termier, G., Vachard, D., 1977. Biostratigraphie des terrains du Maroc central depuis le Givetien jusqu'au Namurien inférieur. Vlème colloque africain de Micropaléontologie, Tunis. Annales des Mines et de la Géolologie 28, 39-63.

Xu, H.H., Wang, Y., 2008. The palaeogeographical significance of specimens attributed to Protolepidodendron scharyanum Krejci (Lycopsida) from the Middle Devonian of North Xinjiang China. Geological Magazine 145, 295-299.

Xu, H.H., Berry, C.M., Wang, Y., Marshall, J.E.A., 2011. A new species of Leclercqia Banks, Bonamo et Grierson (Lycopsida) from the Middle Devonian of North Xinjiang, China, with a possible climbing habit. International Journal of Plant Sciences 172, 836-846.

Zdebska, D., 1982. A new zosterophyll from the Lower Devonian of Poland. Palaeontology 25, 247-263. 